\title{
Jejunum and Ileum Neuroendocrine Tumor cM1b TNM Finding v8
}

National Cancer Institute

\section{Source}

National Cancer Institute. Jejunum and lleum Neuroendocrine Tumor cM1b TNM Finding v8. NCI Thesaurus. Code C135099.

Jejunum and ileum neuroendocrine tumor with metastasis in at least one extrahepatic site (e.g., lung, ovary, nonregional lymph node, peritoneum, bone). (from AJCC 8th Ed.) 